\title{
A Case of Hamartoma of the Subglottis
}

\author{
Myung Jun Lee ${ }^{1}$, Joo Yeon Kim ${ }^{2}$, Hye-Kyung Shim ${ }^{3}$, and Mi Ra Kim ${ }^{1}$ \\ ${ }^{1}$ Departments of Otorhinolaryngology-Head and Neck Surgery, ${ }^{2}$ Pathology, ${ }^{3}$ Nuclear Medicine, Inje University College of Medicine, \\ Haeundae Paik Hospital, Busan, Korea
}

\author{
성문하부에 발생한 과오종 1예 \\ 이명준 ${ }^{1} \cdot$ 김주연 $^{2} \cdot$ 심혜경 ${ }^{3} \cdot$ 김미라 $^{1}$ \\ 인제대학교 의과대학 해운대백병원 이비인후과학교실, ${ }^{1}$ 병리학교실, ${ }^{2}$ 핵의학교실 ${ }^{3}$
}

\author{
Received November 13, 2016 \\ Revised January 26, 2017 \\ Accepted February 7, 2017 \\ Address for correspondence \\ Mi Ra Kim, MD, PhD \\ Department of Otorhinolaryngology- \\ Head and Neck Surgery, \\ Inje University College of Medicine, \\ Haeundae Paik Hospital, \\ 875 Haeun-daero, Haeundae-gu, \\ Busan 48108, Korea \\ Tel $+82-51-797-2290$ \\ Fax $+82-51-797-0298$ \\ E-mail enthns@hanmail.net
}

\begin{abstract}
Hamartoma is a developmental anomaly or non-neoplastic malformations composed by an excessive growth of indigenous mature tissue present in wrong proportions and abnormal arrangements. Hamartomas may develop in all areas of the body but it is extremely rare in the larynx. The treatment of hamartomas consists of adequate surgical excision leading to an excellent prognosis. We present an incidentally detected subglottic mass during intubation in a 70 -yearold male patient. The mass was excised by transoral laser surgery. Histopathologic examination of the lesion revealed that it consisted of hamartoma.
\end{abstract}

Korean J Otorhinolaryngol-Head Neck Surg 2018;61(7):370-3

Key Words Hamartoma - Subglottic mass - Transoral laser surgery.

\section{서 론}

과오종(hamartoma)은 발생 부위에 있는 고유 조직들 중 하 나 또는 그 이상의 세포 성분이 과도하게 증식하여 형성된 양 성 종양으로, ${ }^{1-6)}$ 아직까지 정확한 원인과 병태 생리는 밝혀져 있지 않지만 선천성, 발생학적 이상 또는 염증에 대한 조직 반응의 결과로 인해 발생하는 것으로 생각되고 있다. ${ }^{34)}$ 과오 종은 신체 어느 부위에서나 발생할 수 있으나, 폐, 간, 신장, 비 장에서 주로 발생한다. 지금까지 국내에서 비강,78) 비인두, ${ }^{6}$ 혀,") 구개편도 ${ }^{4)}$ 에서 발생한 과오종이 보고되었으나, 후두에 서 발생한 과오종은 매우 드문 질환으로 아직까지 국내에서 알려진 바는 없다. 이에 저자들은 증상 없이 전신 마취하에 기 관 삽관 시도 중 우연히 발견된 성문하부 기원의 과오종 1예를 경험하여 문헌고찰과 함께 보고하는 바이다.

This is an Open Access article distributed under the terms of the Creative Commons Attribution Non-Commercial License (https://creativecommons.org/licenses/by-nc/4.0) which permits unrestricted non-commercial use, distribution, and reproduction in any medium, provided the original work is properly cited.

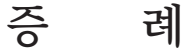

70세 남자 환자로 고혈압, 탈장 수술 과거력 이외에 특이 병력이 없는 분으로 타 병원에서 좌측 횡행 결장암으로 진단 되어 내원 3일 전 수술을 위한 전신 마취 시도 중 우연히 발견 된 상부 기도 종물로 인해 기관 삽관을 실패하여 진단 및 치 료를 위해 본원 호흡기 내과로 전원 이후 이비인후과로 협진 의뢰되었다. 환자는 애성, 호흡곤란, 연한곤란, 기침 등의 증 상이 전혀 없었으며, 신체 진찰에서 구강이나 경부에 특이 소 견은 관찰되지 않았다. 환자는 타 병원에서 대장암에 대한 전신 전이 검사 및 흥부 $\mathrm{CT}$ 를 시행하여 성문하부와 상부기관 에 국한된 석회화를 동반한 종물을 확인하였다. 수술 7일 전 기관지 내시경(Fig. $1 \mathrm{~A}$ ) 검사에서 정상적인 성대 움직임을 확 인한 이후 성문하부로 기관지 내시경을 진입하면서 정상 점 막으로 덮여 있으며 울퉁불퉁한 돌기를 가진, 기도 내강으로 돌출된 종물을 확인하였다. 성문하부와 상부 기관은 종물에 의해서 내경이 $70 \%$ 가량 좁아져 있어 간신히 $6 \mathrm{~mm}$ 직경의 기 
관지 내시경이 통과할 수 있었다. 기관지 내시경을 이용한 조직 검사를 시행하였으며, 종물이 매우 딱딱하였으며, 부분적인 석회화를 동반한 정상 기도 점막이 확인되었다. 병변의 기시 부와 후두 골격과의 관계 및 범위를 정확히 확인하기 위하여 후두 내시경 검사를 시행하였고(Fig. 1B), 영상의학과와 협진 시행 후 수술 5일 전 후두 MRI를 촬영하였다. 후두 MRI(Fig. 2)에서는 좌측 윤상연골의 내벽에서 시작하여 기도 내강으로 돌출되는 양상의 지방과 석회화 성분을 함유한 $1.4 \times 1.4 \times 2$ $\mathrm{cm}$ 크기의 종물을 관찰하였다.

환자는 마취과, 일반외과, 호흡기내과와 상의 이후 우선적 으로 이비인후과에서 기도 확보를 위하여 기관절개술 시행 후 기관 절개공을 통한 전신 마취 유지하에 일반외과에서 좌 측 횡행 결장암 수술을 진행하기로 결정하였다. 국소 마취하 에 세 번째 기관 연골에 기관절개술을 시행하여 기도를 확보 한 후, 기관 절개공을 통하여 후두내시경을 이용하여 좌측에 성문하부 윤상연골에서 기원하는 넓은 기저부를 가진 종물을 관찰하였다. 현수 후두경을 이용하여 성문하부를 노출하고 윤상연골을 보존하기 위하여 윤상연골에서 1 2 $\mathrm{mm}$ 떨어져 $\mathrm{CO}_{2}$ 레이저를 이용하여 점막 절개를 시행한 후 석회화된 병변
을 확인하였으며, $\mathrm{CO}_{2}$ 레이저, 겸자, 미세수술용 가위를 이용 하여 윤상연골을 보존하면서 석회화를 포함한 세 조각으로 제거하였다. 일반외과에서는 복강경을 통한 좌측 결장 절제 술 및 하장간막 동맥 보존 림프절 곽청술을 시행하고 수술을 마쳤다.

병리조직학적 검사에서 수술 후 세 조각으로 제거된 종물 중 가장 큰 절편은 $1.5 \times 0.7 \times 0.7 \mathrm{~cm}$ 의 정상 호흡 상피세포로 덮 여 있는, 다양한 크기의 혈관을 포함한 성긴 섬유성 결합조 직을 바탕으로 성숙한 골주와 연골 조직으로 구성된 과오종 으로 진단되었으며, 주변 조직으로의 침습이나 이형성증, 악 성세포로의 변화는 관찰되지 않았다(Fig. 3). 좌측 횡행 결장 암 수술 후 병리조직검사에서는 결장 주변 림프절(pericolic lymph node) 전이를 동반한 선암(adenocarcinoma)으로 7th $\mathrm{AJCC}$ 분류에 의한 TNM 병기에 의하여 $\mathrm{T} 3 \mathrm{~N} 1 \mathrm{bM} 0$ 로 진단되 어 수술 후 항암치료를 계획하였다. 수술 후 정상적인 성대 움 직임을 보이고 기도 유지에 어려움이 없어 2주 후 발관 및 기 관 절개공을 봉합하였고 특별한 합병증 없이 퇴원하였다. 결 장암 수술 후 항암치료를 위해 일반 외과 진료 중이며, 윤상 연골의 좌측 내벽 기시부에서의 과오종의 재발이나 호흡 관련
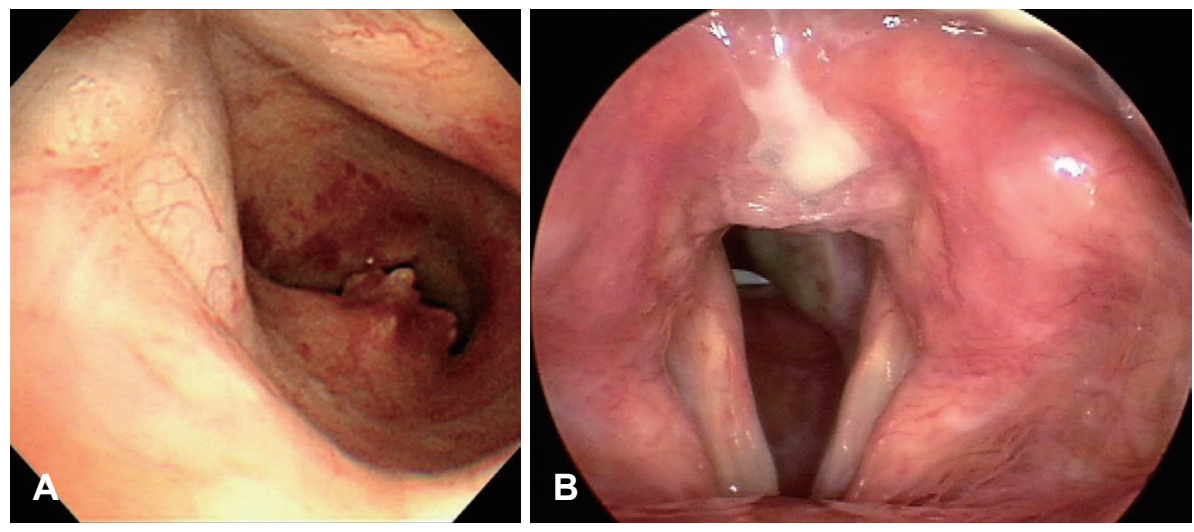

Fig. 1. Preoperative bronchoscopy and laryngoscopy findings in the patient. At bronchoscopic examination (A) and laryngoscopic findings after bronchoscopic guided biopsy (B), intraluminally protruding irregular contour lesion covered with smooth mucosa was observed in the subglottis and upper trachea originated from left inner wall of cricoid cartilage with a broad base, obliterating the tracheal lumen by $70 \%$.
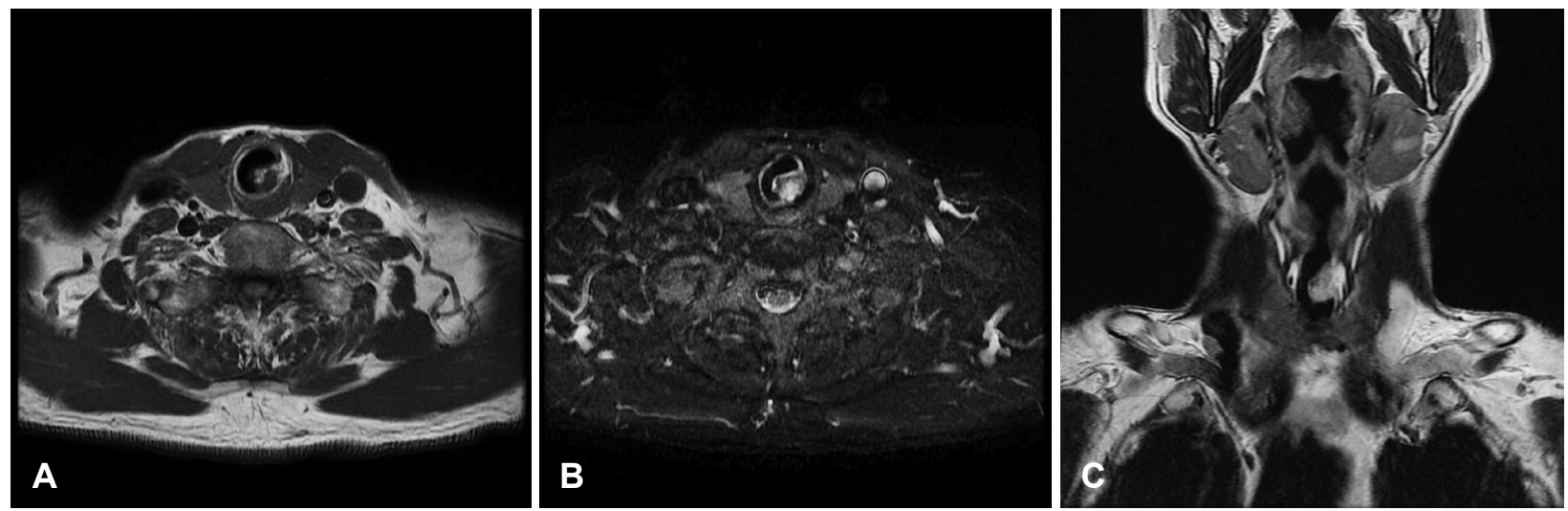

Fig. 2. Preoperative MRI findings in the patient. Axial view shows smooth marginated, intraluminally protruding mass arising from left inner wall of cricoid cartilage and upper trachea, about $1.4 \times 1.4 \times 2 \mathrm{~cm}$. That mass contains fat and calcification with continuing laryngeal mucosa and shows heterogenous signal on T1 (A), T2 (B) with peripheral enhancement. It seems to be subglottic laryngeal tumor, such as hamartoma or chondroma. Coronal MRI (T2) shows high signal in left cricoid cartilage and upper trachea (C). 


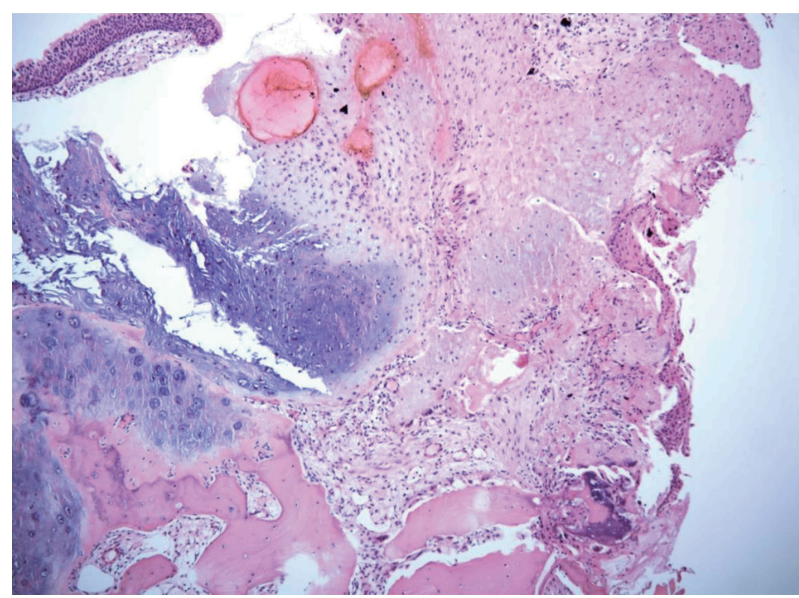

Fig. 3. The submucosal lesion shows multinodular chondroid tissue and mature bony trabecula. Also there are variable sized blood vessels present in the fibromyxoid background $(\times 400)$.

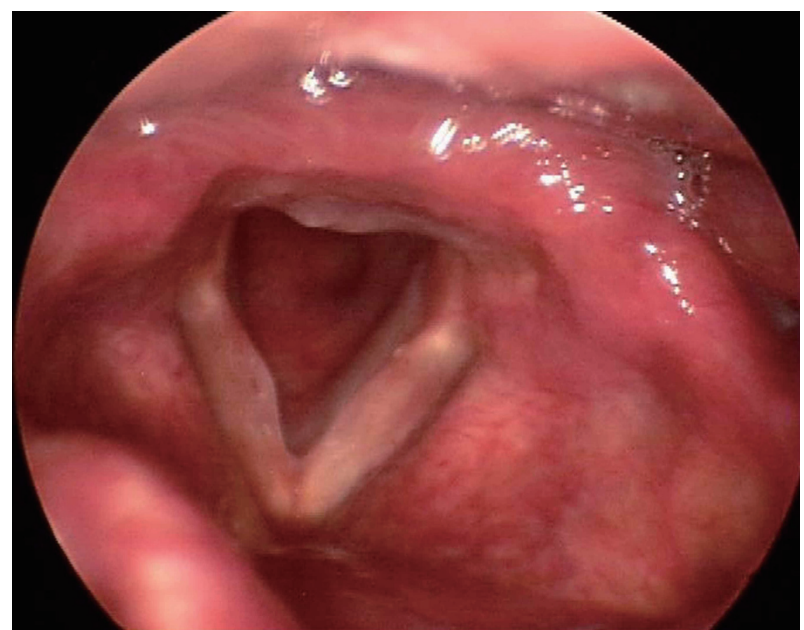

Fig. 4. Postoperative laryngoscopic findings two months after surgery. There is no recurrence of subglottic mass arising from left inner wall of cricoid cartilage.

증상, 음성 변화 없이 4개월째 추적관찰 중이다(Fig. 4).

\section{고 찰}

과오종 자체로 인한 증상은 거의 없거나 비특이적인 증상을 보이다가, 크기가 증가하면서 발생 부위에 따른 압박 증상을 나타낸다. ${ }^{2,3,5,10)}$ 후두에서 발생한 과오종은 국외 문헌을 고찰 하였을 때, 크기와 위치에 따라 다양한 증상을 보인다. 영유 아에서 발생한 과오종은 호흡곤란, 천명, 기도 폐쇄 증상을 주증상으로 나타냈으며, $1,5,10-13)$ 성인에서는 장기간 서서히 진행 하는 호흡곤란 증상으로 천식, 폐쇄성 폐질환으로 오인될 수 있는 증례 보고 ${ }^{2,314)}$ 를 확인할 수 있었다. 진단을 위한 영상학 적 검사(CT, MRI)가 종물의 크기, 위치, 범위를 확인하는 데 유용한 검사 방법이며, 내시경을 통한 종물의 확인과 내시경
하 조직검사가 진단에 있어 중요하다. 후두 과오종은 대부분 점막하 종물로 관찰되므로, 내시경 검사와 영상학적 검사를 종합하여 적절한 수술 방법과 범위를 결정하는 것이 중요하 다. 본 증례 또한 기관지 내시경을 통하여 점막하 병변을 확 인하였고, 내시경하 조직검사에서 어려움이 있어 영상학적 검 사(MRI)를 함께 시행하여 윤상연골에서 기원한 성문하부의 양성 후두 종양을 가장 먼저 고려하였다.

과오종은 병리조직학적으로 유래된 조직에 따라 연골과 혈 관, 지방 등의 간엽조직에서 유래된 간엽성 과오종과 상피와 분비선 등의 상피조직에서 유래된 상피성 과오종으로 크게 나누어지며,8,15) 본 증례는 성숙한 골조직과 연골조직으로 구 성된 골성-연골성(osteo-chondroid) 과오종으로 구성 세포의 이형성증이나 악성 변화는 극히 드물다.710,13)

과오종은 세포 증식을 통해 서서히 자라면서 증상을 야기 하고, 매우 드물지만 악성화의 가능성이 있으므로, 수술을 통 한 과오종의 완전 절제가 가장 좋은 치료 방법이다.,10) 불완전 하게 절제될 경우 재발의 원인이 될 수 있으며, ${ }^{10)}$ 완전 절제 이 후의 예후는 매우 양호하다. ${ }^{3,10}$ 후두에서 발생한 과오증은 양 성 종양으로 기도 확보와 함께 후두 기능을 보존하면서 종물 의 완전 절제가 중요하다. ${ }^{1,2)}$ 기도 확보를 위한 기관절개술을 함께 시행할 수 있으며, 병변의 범위에 따라 현수 후두경을 이 용한 경구강 접근법으로 절제하는 경우, 경부 접근법을 통해 서 후두 부분 절제까지 시행할 수 있다. ${ }^{2,3,11)}$ 후두 기능을 보존 하기 위하여 현수 후두경하에 경구강 레이저 절제술은 충분 한 수술 시야를 확보하면서 레이저를 이용하여 종물의 절제 범위를 확인하면서 출혈을 최소화할 수 있는 효과적인 치료 방법이다. ${ }^{2,3,10}$ 본 증례에서는 대장암에 대한 빠른 수술적 치 료가 필요하여 우선 기관절개술을 시행하여 기도를 확보하였 다. 윤상 연골 기원의 종물로서 영구적인 기관절개술을 피하 고, 대장암의 치료를 지연시키지 않기 위하여 경부 접근법보 다는 경구강 레이저 수술을 통한 절제술을 우선적으로 계획 하였다. 현수 후두경을 이용하여 병변의 범위를 확인한 후, 충분한 수술 시야 확보가 가능하여 경구강 레이저 절제술을 시행하였다. 레이저를 이용하여 출혈을 최소화할 수 있었으나, 병변이 윤상 연골에서 기시하여 성문하부 및 기관으로 진행하 는 양상을 보여 병변의 절제 범위 확인과 절제에 용이한 기구 선택에 있어서 다소 어려움이 있었다. 과오종을 불완전하게 절제할 경우 재발이 있을 수 있다. 본 증례에서는 후두의 기능 및 구조 유지를 위해 윤상연골 기시부를 보존하였기 때문에 재발 및 드물지만 악성 변화의 가능성을 고려하여 후두내시 경을 통한 정기적인 관찰을 시행하고 있다. 4 개월째 추적관찰 중 재발되지 않았으며 후두 기능 장애, 음성 변화도 발생하지 않았다. 
후두에서 발생한 과오종은 매우 드문 양성 질환으로 적절 한 기도 확보와 종물의 완전 절제가 가장 좋은 치료 방법이 다. 하지만 다른 후두 종양과 감별 진단을 못할 경우 불필요 한 근치적 수술을 시행할 수 있으므로 영상검사 결과와 내시 경 소견, 조직학적 소견을 종합하여 후두 기능을 최대한 보 존하면서 과오종에 대한 수술적 치료를 시행하는 것이 중요 하다.

\section{REFERENCES}

1) Yigitbasi OG, Guler G, Ozturk F, Guney E. Glandular hamartoma of the larynx. Int J Pediatr Otorhinolaryngol 2002;65(2):163-6.

2) Mäkitie AA, Lehtonen H, Bäck L, Aaltonen LM, Leivo I. Hamartoma of the larynx: an unusual cause of dyspnea. Ann Otol Rhinol Laryngol 2003;112(10):841-3.

3) Buckmire RA, Kwon TK. Bilateral obstructing laryngeal epithelial adenomatous hamartomas. Arch Otolaryngol Head Neck Surg 2005; 131(3):259-61.

4) Na HG, Bae CH, Kim YD, Song SY. A case of hamartoma originated from the palatine tonsil. Korean J Otorhinolaryngol-Head Neck Surg 2011;54(10):731-3.

5) Uçar Ş, Zorlu P, Yıldırım I, Metin Ö. Hamartoma of the larynx: an unusual cause of stridor. Balkan Med J 2014;31(4):349-51.

6) Kim KM, Kwon SH, Park HS, Kang MJ. A case of mixed epithelial and mesenchymal hamartoma of nasopharynx. Korean J OtorhinolaryngolHead Neck Surg 2012;55(3):191-3.

7) Lee HK, Cho KJ, Jung SH, Kim NS. A case of fibro-osseous hamartoma originated from nasal cavity. Korean J Otorhinolaryngol-Head Neck Surg 2008;51(5):495-8.

8) Park KH, Kwon SU, Yoon SW, Joo JE. A case of adenomatoid hamartoma originated from nasal cavity. Korean J Otolaryngol-Head Neck Surg 2004;47(12):1323-5.

9) Park JB. A rare case of hamartoma of the tongue. Korean J Otorhinolaryngol-Head Neck Surg 1975;18(1):57-9.

10) Leoncini G, Maio V, Mirabile L, Baggi R, Franchi A. Glandular hamartoma of the larynx: report of a case. Auris Nasus Larynx 2008; 35(1):149-51.

11) Archer SM, Crockett DM, McGill TJ. Hamartoma of the larynx: report of two cases and review of the literature. Int J Pediatr Otorhinolaryngol 1988;16(3):237-43.

12) Daniel SJ. The upper airway: congenital malformations. Paediatr Respir Rev 2006;7 Suppl 1:S260-3.

13) Kşlal FM, Acar M, Acar B, Karahan F. Laryngeal fibrous hamartoma presenting with airway obstruction at birth. J Craniofac Surg 2013; 24(4):e383-4.

14) Cetinkaya E, Gunluoglu G, Eyhan S, Gunluoglu MZ, Dincer SI. A hamartoma located in the trachea. Ann Thorac Cardiovasc Surg 2011;17(5):504-6.

15) Park SK, Jung H, Yang YI. Mesenchymal hamartoma in nasopharynx: a case report. Auris Nasus Larynx 2008;35(3):437-9. 